\title{
COMPARISON OF ACTIONS OF PAPAVERINE, ASPAMINOL AND ISOPRENALINE ON ISOLATED RAT UTERUS
}

\author{
Tsutomu URUNO, Issei TAKAYANAGI*, Kazuhiko KUBOTA \\ and Keijiro TAKAGI* \\ Department of Pharmacology, Faculty of Pharmaceutical Sciences, Science University \\ of Tokyo, Shininku-ku, Tokyo. and Department of Chemical Pharmacology. Faculty \\ of Pharmaceutical Sciences, University of Tokyo,* Bunkyo-ku, Tokyo, Japan
}

Accepted July 24, 1973

\begin{abstract}
Inhibitory responses of the isolated rat uterus to papaverinc, Aspaminol and isoprenaline were potentiated by aminophylline that inhibits phosphodiesterase. The inlibitory responses to papaverine and isoprenaline were decreased by imidazole that stimulates phosphodiesterase activity, while the inhibitory response to Aspaminol was little influenced by imidazole. Papaverine strongly inhibited phosphodiesterase from the rat uterus, but Aspaminol did not infuence phosphodiesterase activity. These results indicate that papaverine and isoprenaline are mediated through an increase of the intracellular level of cyclic AMP and also indicate that the inhibitory response of the rat uterus to Aspaminol is not concerned with the amount of intracellular cyclic AMP increased by inhibiting phosphodiesterase. Further, the results support the theory that there are two mcchanisms for the so-called papaverine-like antispasmodics.
\end{abstract}

The beta-adrenergic action is thought to be related to the ability of the beta-adrenergic stimulants to increase the intracellular level of adenosine 3', 5'-monophosphate (cyclic AMP) in the smooth muscle (1). Recently evidence is presented that papaverine, a smooth muscle relaxant, is a potent inhibitor of phosphodiesterase in rabbit aorta, rat uterus and guinea pig ileum $(2,3)$. More recently certain workers $(4,5,6,7,8)$ have reported that papaverine and isoprenaline increased the intracellular level of cyclic AMP in the intestinal and uterine smooth muscle. These results indicate the possibility that the actions of betaadrenergic stimulants and papaverine are mediated through an increase of the intracellular level of cyclic AMP.

Takagi, Takayanagi and Fujie (9) suggested that the mechanisms of action for papaverine are different from those for synthetic antispasmodics such as benactyzine and Aspaminol (1, 1-diphenyl-3-piperidinobutanol hydrochloride). This theory was confirmed by Takagi et al. (10). Therefore, we have compared the mode of action of Aspaminol with those of papaverine and isoprenaline.

\section{MATERIALS AND METHODS}

Virgin female Wistar rats weighing 150 to $200 \mathrm{~g}$ were ovariectomized and allowed to recover more than 5 days before beginning an experiment.

Oxytocin-induced Contractions

An ovariectomized rat was stunned and bled, and the uterine horns were removed. 
One horn was suspended in a $10 \mathrm{ml}$ organ bath. The bath was filled with Locke-Ringer"s solution, kept at $32 \mathrm{C}$, and gassed with a mixture of $95 \% \mathrm{O}_{2}$ and $5 \% \mathrm{CO}_{2}$. Locke-Ringer's solution had the following composition: $9.0 \mathrm{~g}$ of $\mathrm{NaCl}, 0.4 \mathrm{~g}$ of $\mathrm{KCl}, 0.2 \mathrm{~g}$ of $\mathrm{CaCl}_{2}, 0.2$ $\mathrm{g}$ of $\mathrm{MgCl}_{2}, 0.5 \mathrm{~g}$ of $\mathrm{NaHCO}_{3}$ and $0.5 \mathrm{~g}$ of glucose in a litre. Uterine contractions were isotonically recorded by means of a lever loaded with $0.5 \mathrm{~g}$ on a smoked drum. A concentration-action curve was cumulatively obtained $(11,12)$. The contractions are expressed as the percentage of the maximum response and each curve represents the mean of at last six exporiments.

To compare the effects of the test drugs on the uterine muscle with those on the intestinal muscle, the taenia from the guinea pig caecum was used in some experiments. The inhibitory effects of Aspaminol and isoprenaline in the presence and absence of caffeine or imidazole on the tamia were investigated. After sacrificing a male guinea pig (300 to $350 \mathrm{~g}$ in body w.) by a blow on the neck, the taenia was isolated from the caceum. A pice of the taenia was suspended in a $10 \mathrm{ml}$ organ bath filled with Loke-Ringer's solution, and kept at $37^{\circ} \mathrm{C}$. Other experimental conditions were the same as those used for the rat uterus. Anti-phosphodicsterase activity of rest divgs

The uteri isolated from five ovariectomized rats were homogenized with the 10-fold of a buffer- $\mathrm{Mg}^{2+}$-solution (Tris- $\mathrm{HCl} 16 \div 10^{-2} \mathrm{M}, \mathrm{Mg}$-acetate $5 \times 10^{-3} \mathrm{M} ; \mathrm{pH} 7.5$ ) at $0^{\circ} \mathrm{C}$ according to the method of Pöch (13). The homogenate was centrifuged at $2,000 \times \mathrm{g}$ for $15 \mathrm{~min}$ at $0 . \mathrm{C}$ and the homogenate fuid was used as enzyme preparation.

Phosphodiesterase activity was assayed according to Pöch (13). The principle of the determination of phosphodiesterase-activity used is based on the decrease in radioactive substrate ( ${ }^{3} \mathrm{H}$-cyclic AMP) during incubation with tho enzyme. This decrease can be measured since the product of the reaction, labeled 5'-AMP, in contrast to the substrate can be removed from the reaction mixture by $\mathrm{ZnSO}_{4}-\mathrm{Ba}(\mathrm{OH})_{2}$-precipitation (14). Nonlabeled 5'-AMP was added in a high concentration (1 mM) which did not interfere with the phosphodiesterase-reaction since the reaction product, labeled $5^{\prime}$-AMP, is further metabolized in crude enzyme preparations which contain varying amounts of $5^{\prime}$-nueleotidase. Incubation was carried out at $37^{\circ} \mathrm{C}$ for $30 \mathrm{~min}$ with $300 / 4$ supernatant (corresponding to $12 \mathrm{mg}$ wet wt), to which 50 , ll of non-labeled 5-AMP (adjusted to $\mathrm{pH} 7.5$ and 50 or $100, n$ of a test drug-solution were added. The reaction was started by the addition of 50,2$\}$ of the labeled substrate. The reaction volume always $500, z l$. The Michalelis constant $(\mathrm{K} \cdot \mathrm{m})(15)$ and inhibitor constant (Ki) (16) were graphically determined.

Druss used: Papaverine hydrochtoride (Tokyo Kasei Kogyo). Aspaminol (1, 1diphenyl-3-piperidinobutanol hydrochloride, Kowa Co. Ltd.) L-isoproterenol-D-bitartrate (Sigma). Caffeine (Wako Pure Chemical Industries, Ltd.). Aminophylline ((Theophylline) ${ }_{2}$ ethylenedianine, Sigma). Imidazole (Tokyo Kasei Kogyo). Oxytocin (Atonin-S, Teikoku Zoki). Cyclic 3', 5'-A MP (adenosine-3', 5'-monophosphate, Daiichi Pure Chemicals, Co, Lid.). 5'AMP (adenosine-5'-monophosphate, Daiichi Pure Chemicals, Co. Ltd.). ${ }^{3}$ H-cyclic 3', 5'-AMP (adenosine-8-labeled, Daiichi Pure Chemicals, Co. Ltd., specific activity $7.7 \mathrm{Ci}$ mmole). 


\section{RESULTS}

Effects of aminophylline and imidazole on inhibitory responses of the rat uterus to Aspaminol, papaverine and isoprenaline

Fig. 1 shows the effects of Aspaminol, papaverine and isoprenaline on the oxytocininduced contractions in the presence and absence of aminophylline in the isolated rat uterus. The inhibitory actions of isoprenaline $\left(2 \times 10^{-10} \mathrm{~g} / \mathrm{ml}\right)$ and Aspaminol $\left(10^{-5} \mathrm{~g} / \mathrm{ml}\right)$ were greatly potentiated by aminophylline $\left(5 \times 10^{-5} \mathrm{~g} / \mathrm{ml}\right.$ ) (Fig. 1, A, C). On the other hand, aminophylline $\left(5 \times 10^{-5} \mathrm{~g} / \mathrm{ml}\right)$ also potentiated the inhibitory action of papaverine $\left(10^{-6} \mathrm{~g} / \mathrm{ml}\right)$ (Fig. 1. B). This potentiation was not so great as those of the actions of isoprenaline and Aspaminol by aminophylline.

In the presence and absence of imidazole the inhibitory responses to Aspaminol, papaverine and isoprenaline are shown in Fig. 2. Imidazole greatly antagonized the responses to isoprenaline $\left(2 \times 10^{-10} \mathrm{~g} / \mathrm{ml}\right)$ and papaverine $\left(10^{-6} \mathrm{~g} / \mathrm{ml}\right)$ at the concentrations of $5 \times$ $10^{-5} \mathrm{~g} / \mathrm{ml}$ and $3 \times 10^{-4} \mathrm{~g} / \mathrm{ml}$ respectively (Fig, 2. A, B). Imidazole $\left(3 \times 10^{-4} \mathrm{~g} / \mathrm{ml}\right.$ ), however, little influenced the response to Aspaminol $\left(2 \times 10^{-5} \mathrm{~g} / \mathrm{ml}\right)$ (Fig. 2. C). Similar results were obtained with caffeine $\left(10^{-4} \mathrm{~g} / \mathrm{ml}\right)$.

In the taenia isolated from the guinea pig caecum, the inhibitory response to Aspaminol was little influenced by caffeine $\left(10^{-4} \mathrm{~g} / \mathrm{ml}\right)$ or imidazole $\left(10^{-4} \mathrm{~g} / \mathrm{ml}\right)$ (Fig. 3. A, B),
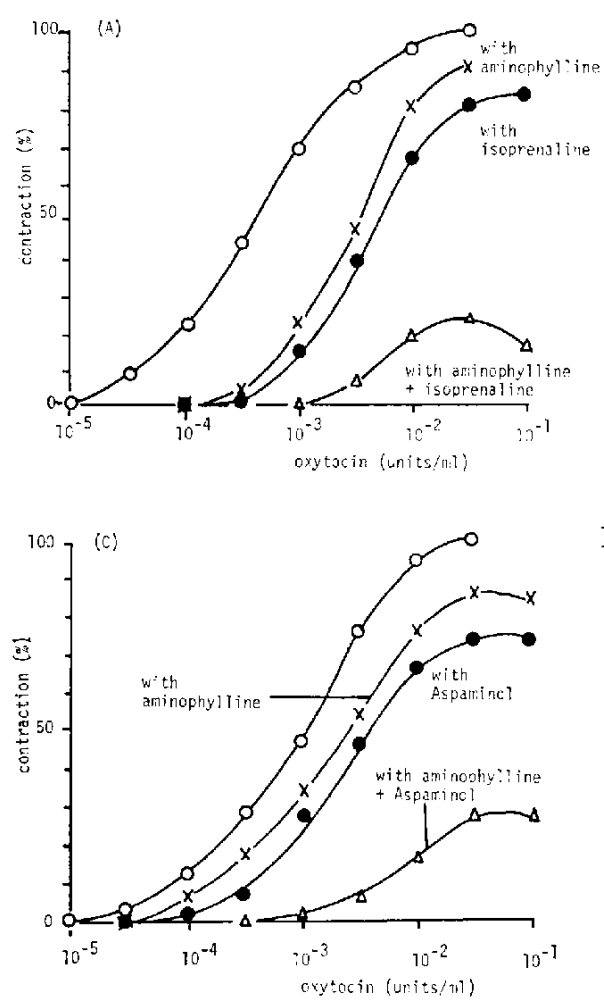

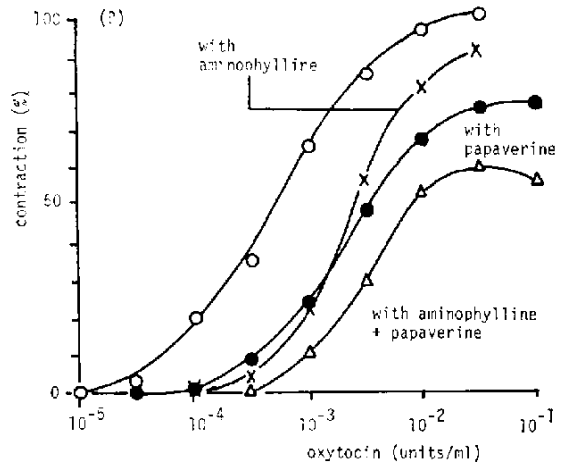

FIG. 1. Effect of aminophylline $\left(5 \times 10^{-5} \mathrm{~g} / \mathrm{ml}\right)$ on the actions of (A) isoprenaline $(2 \times$ $\left.10^{-10} \mathrm{~g} / \mathrm{ml}\right)$, (B) papaverine $\left(10^{-6} \mathrm{~g} / \mathrm{ml}\right)$ and (C) Aspaminol $\left(10^{-5} \mathrm{~g} / \mathrm{ml}\right)$ on oxytocin-induced contractions.

The rat uterus was incubated with isoprenaline, papaverine and Aspaminol for 3 min respectively. After 5 min incubation of the uterus with aminophylline, each antagonist was added. In their presence, cumulative concentration action curves of oxytocin were obtained. 

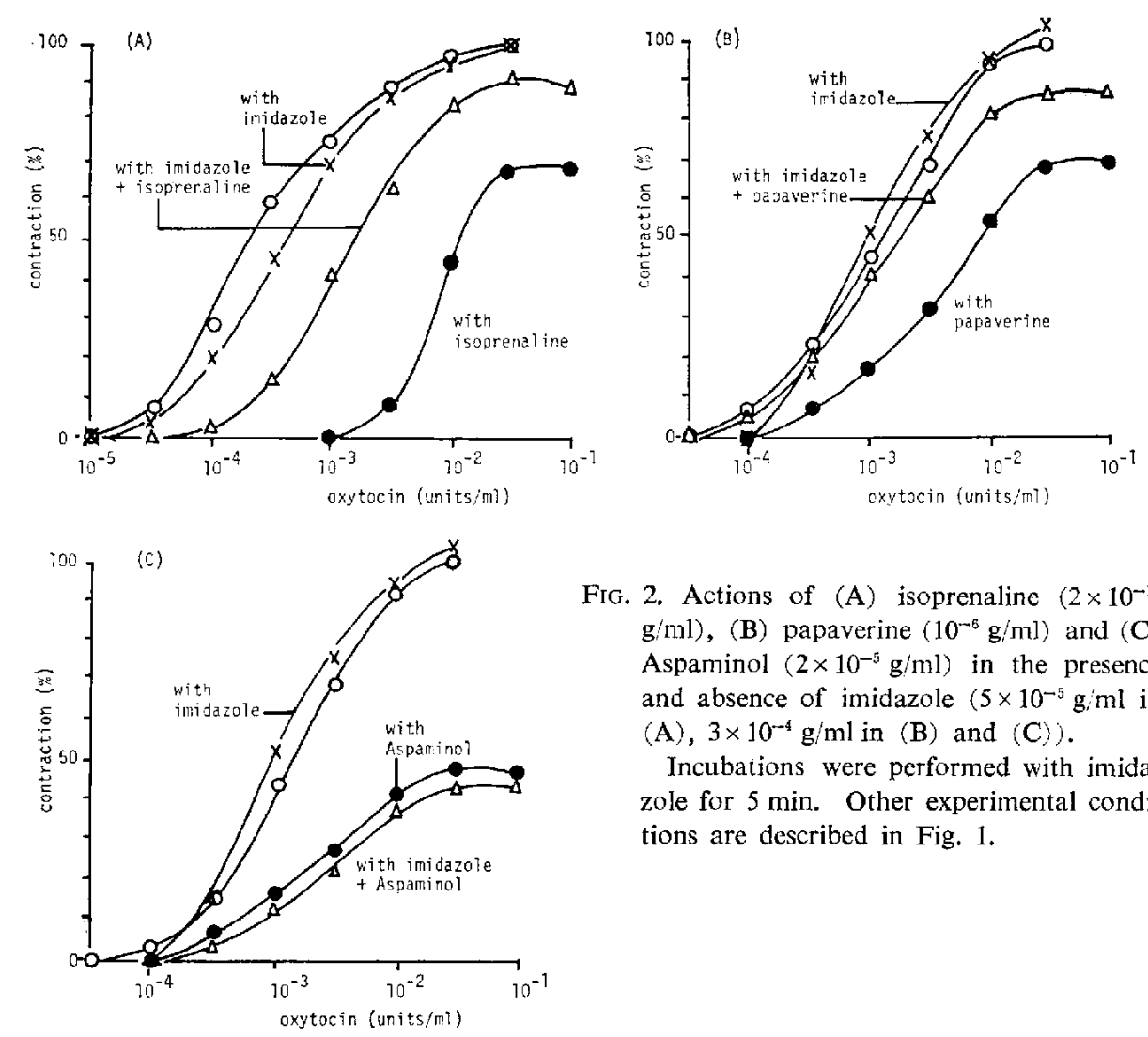

FIG. 2. Actions of (A) isoprenaline $\left(2 \times 10^{-10}\right.$ $\mathrm{g} / \mathrm{ml})$, (B) papaverine $\left(10^{-6} \mathrm{~g} / \mathrm{ml}\right)$ and (C) Aspaminol $\left(2 \times 10^{-5} \mathrm{~g} / \mathrm{ml}\right)$ in the presence and absence of imidazole $\left(5 \times 10^{-5} \mathrm{~g} / \mathrm{ml}\right.$ in (A), $3 \times 10^{-4} \mathrm{~g} / \mathrm{ml}$ in (B) and (C)).

Incubations were performed with imidazole for $5 \mathrm{~min}$. Other experimental conditions are described in Fig. 1.

although the response to isoprenaline was potentiated by caffeine $\left(10^{-4} \mathrm{~g} / \mathrm{ml}\right)$ and antagonized by imidazole $\left(10^{-4} \mathrm{~g} / \mathrm{ml}\right)$ as it did in the rat uterus.

Fig. 4 shows the antagonism betwee aminophylline and imidazole on the inhibitory responses to Aspaminol, papaverine and isoprenaline. It was later confirmed that the inhibitory responses to Aspaminol, papaverine and isoprenaline were potentiated by aminophylline $\left(5 \times 10^{-5} \mathrm{~g} / \mathrm{ml}\right)$, those to Aspaminol, papaverine and isoprenaline were again obtained in the presence of both aminophylline $\left(5 \times 10^{-5} \mathrm{~g} / \mathrm{ml}\right)$ and imidazole $\left(3 \times 10^{-4} \mathrm{~g} / \mathrm{ml}\right)$. The responses to isoprenaline $\left(2 \times 10^{-10} \mathrm{~g} / \mathrm{ml}\right)$ and papaverine $\left(10^{-6} \mathrm{~g} / \mathrm{ml}\right)$ were greatly reduced by application of both aminophylline and imidazole, while the inhibitory response to Aspaminol was little influenced (Fig. 4. C).

\section{Effects of Aspaminol and papaverine on phosphodiesterase activity}

Phosphodiesterase activity was determined by incubating the substrate $\left(10^{-4} \mathrm{M}\right)$ in the presence of $1 \mathrm{mM} 5^{\prime}$-AMP with a 25 -fold crude phosphodiesterase at $37^{\circ} \mathrm{C}, \mathrm{pH} 7.5$, for $30 \mathrm{~min}$. Papaverine at the concentrations of 1,3 and $10 \times 10^{-5} \mathrm{~g} / \mathrm{ml}$ decreased phosphodiesterase activity by 16.8, 61.2 and $94.9 \%$ respectively and a dose-dependent inhibition was found with papaverine, while Aspaminol did not influence phosphodiesterase activity (Table 1). Moreover, aminophylline potentiated the action of papaverine on phosphodiesterase activity but not on that of Aspaminol (Table 2). 

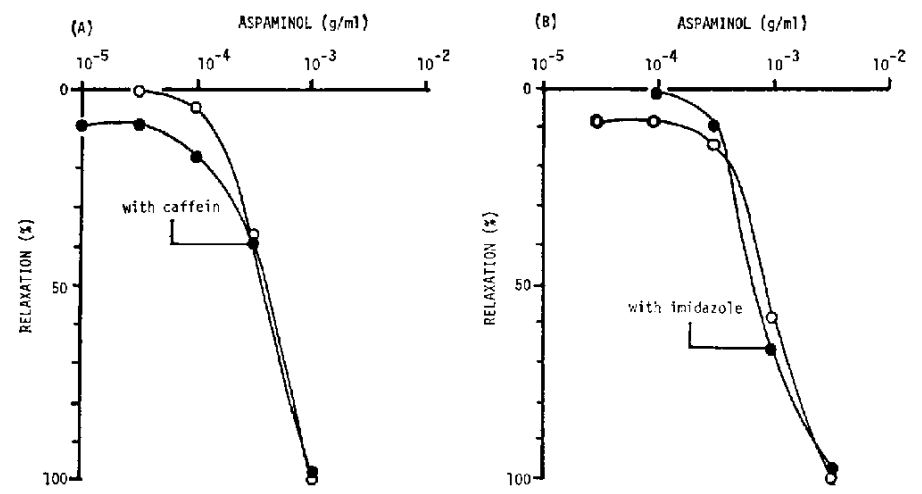

Fig. 3. Effects of (A) caffeine $\left(10^{-4} \mathrm{~g} / \mathrm{ml}\right)$ and (B) imidazole $\left(10^{-4} \mathrm{~g} / \mathrm{ml}\right)$ on an inhibitory action of Aspaminol in taenia.

The taenia from the guinea pig caecum was incubated with caffeine for 20 min and with imidazole for $10 \mathrm{~min}$. The taenia was relaxed by caffeine and recovered to the original base in 15 to $20 \mathrm{~min}$. After that, the concentration action curves were obtained in the presence of caffeine.
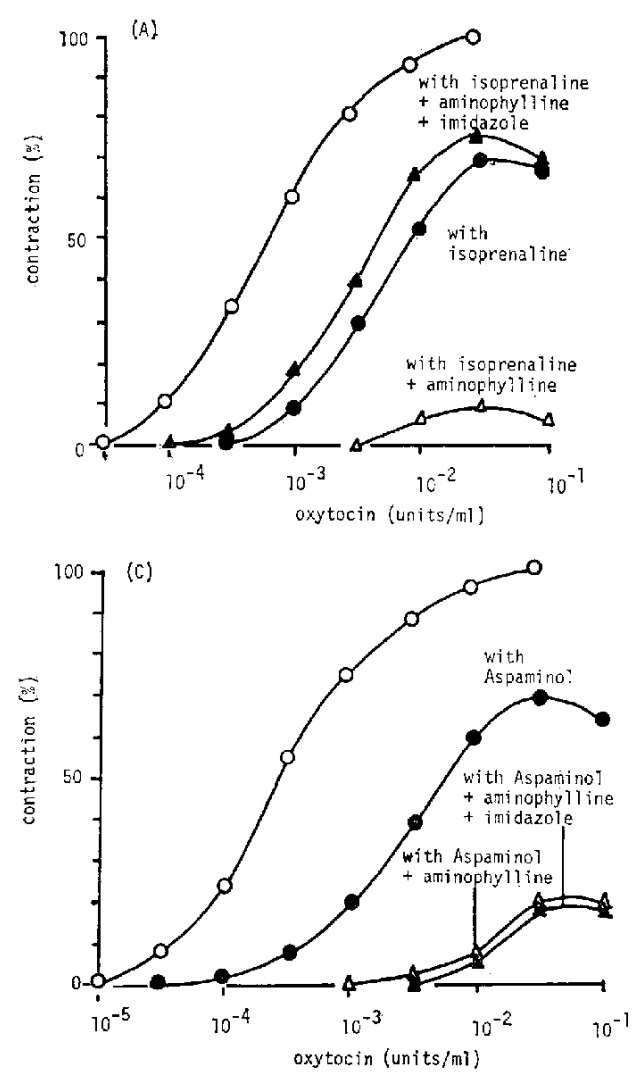

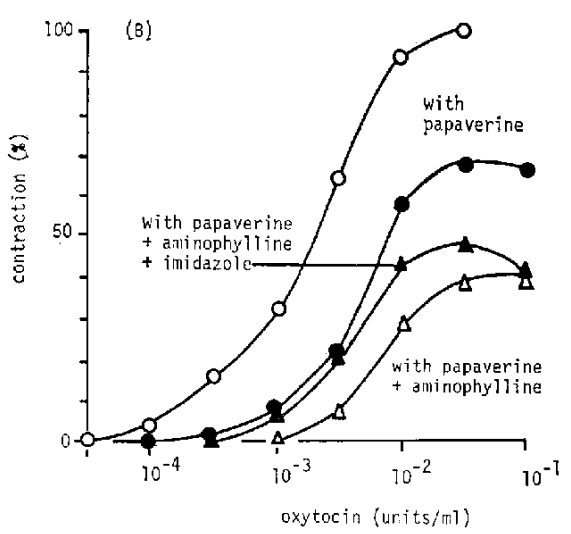

FiG. 4. Antagonism between aminophylline $(5 \times$ $\left.10^{-5} \mathrm{~g} / \mathrm{ml}\right)$ and imidazole $\left(3 \times 10^{-4} \mathrm{~g} / \mathrm{ml}\right)$ on responses to (A) isoprenaline $\left(2 \times 10^{-10} \mathrm{~g} /\right.$ $\mathrm{ml})$, (B) papaverine $\left(10^{-6} \mathrm{~g} / \mathrm{ml}\right)$ and $(\mathrm{C})$ Aspaminol $\left(2 \times 10^{-5} \mathrm{~g} / \mathrm{ml}\right)$.

The uterus was incubated with both aminophylline and imidazole for $5 \mathrm{~min}$. Other experimental conditions are described in Fig. 1. 
TABLE 1. Mean values of percent phosphodiesterase-inhibition by papaverine and Aspaminol and standard error of 3 to 6 estimations.

\begin{tabular}{cccc}
\hline Drug & \multicolumn{3}{c}{ Concentration $(\mathrm{g} / \mathrm{ml})$ in the reaction mixture } \\
& $10^{-5}$ & $3 \times 10^{-5}$ & $10^{-4}$ \\
Papaverine & $16.8 \pm 2.33$ & $61.2 \pm 3.40$ & $94.9 \pm 1.92$ \\
Aspaminol & & $0.7 \pm 1.87$ & $-0.2 \pm 1.20$ \\
\hline
\end{tabular}

TARLE 2. Mean values of percent Phosphodiesterase-inhibition by papaverine and Aspaminol in the presence and absence of aminophylline and standard error of 3 estimations.

* P-value was determined by comparing (A) with (B) or (C) with (D).

\begin{tabular}{lcc}
\hline \multicolumn{1}{c}{ Drug } & $\begin{array}{c}\text { Phosphodiesterase-inhibition (\%) } \\
\text { mean } \pm \text { S.E. }\end{array}$ & P-value* \\
\hline Papaverine $\left(3 \times 10^{-5} \mathrm{~g} / \mathrm{ml}\right)$ & $77.5 \pm 1.99(\mathrm{~A})$ & \\
Aminophylline $\left(10^{-4} \mathrm{~g} / \mathrm{ml}\right)$ & $36.2 \pm 1.05$ & \\
Papaverine $\left(3 \times 10^{-5} \mathrm{~g} / \mathrm{ml}\right)+$ & $84.4 \pm 1.68(\mathrm{~B})$ & $<0.05$ \\
Aminophylline $\left(10^{-4} \mathrm{~g} / \mathrm{ml}\right)$ & $-0.9 \pm 5.36$ & \\
Aspaminol $\left(10^{-4} \mathrm{~g} / \mathrm{ml}\right)$ & $44.9 \pm 2.83(\mathrm{C})$ & \\
Aminophylline $\left(3 \times 10^{-4} \mathrm{~g} / \mathrm{ml}\right)$ & $44.1 \pm 4.58$ (D) & $>0.05$ \\
Aspaminol $\left(10^{-4} \mathrm{~g} / \mathrm{ml}\right)+$ & & \\
Aminophylline $\left(3 \times 10^{-4} \mathrm{~g} / \mathrm{ml}\right)$ & & \\
\hline
\end{tabular}
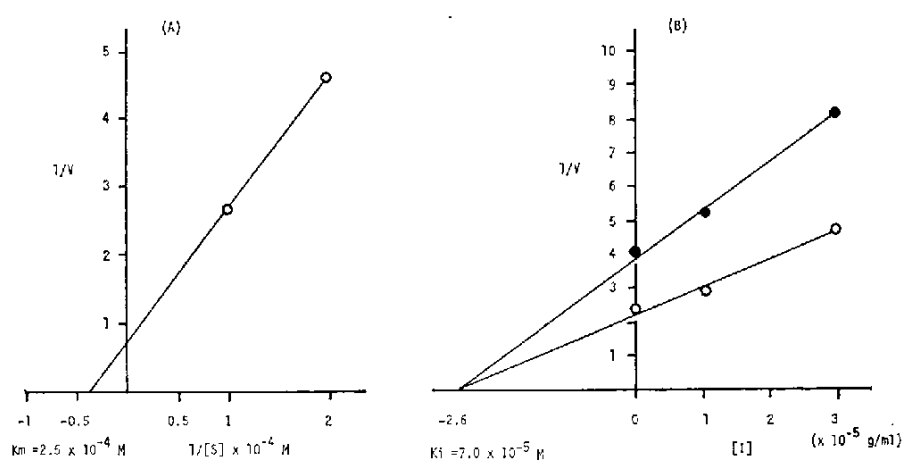

FIG. 5. Estimations of (A) $\mathrm{Km}$ value for cyclic $\mathrm{AMP}$ and (B) $\mathrm{Ki}$ value.

Inhibition of phosphodiesterase by papaverine [I] was measured at two substrate concentrations $\left(\mathrm{O}-10^{-4} \mathrm{M} \longrightarrow 0.5 \times 10^{-1} \mathrm{M}\right)$ and determined from Dixon plots.

The $\mathrm{Km}$ and $\mathrm{Ki}$ values were obtained by incubating the substrate $(0.5$ and $1.0 \mathrm{mM})$ in the presence and absence of papaverine or Aspaminol with a 25 -fold crude preparation of the esterase at $37^{\circ} \mathrm{C}, \mathrm{pH} 7.5$, for $30 \mathrm{~min}$. All determinations were carried out in the presence of $1 \mathrm{mM} 5$-AMP in the reaction mixture. The $\mathrm{Km}$ value for cyclic AMP was $2.5 \times 10^{-4} \mathrm{M}$ (Fig. 5, A). The Ki value was $7.0 \times 10^{-5} \mathrm{M}$ and the type of inhibition was competitive (Fig. 5. B). 


\section{DISCUSSION}

Miznegg, Heim and Meythaler (17) and also Mitznegg, Hach and Heim (18) have shown in isolated rat uterus that exogenously applied cyclic AMP and caffeine inhibit the contractile responses induced by oxytocin, and suggested that caffeine might increase the intracellutar content of cyclic AMP by inhibiting phosphodiesterase. Moreover, Takagi, Takayanagi and Tsuchida (19) using the taenia from the guinea pig caecum, have reported that relaxing actions of papaverine and isoprenaline were affected by caffeine and imidazole. In the present study, the inhibitory actions of isoprenaline and papaverine were potentiated by aminophylline, an agent that inhibits phosphodiesterase, and antagonized by imidazole, an agent that stimulates phosphodiesterase activity, and antagonistic relation between aminophylline and imidazol was observed. These results are in good agrement with those reported previously (19). Further, phosphodiesterase from the rat uterus was competitively inhibited by papaverine, therefore it is suggested that noncompetitive anti-oxytocin action of papaverine might be exerted through its inhibition on phosphoriesterase. In vicw of these results, the inhibitory responses to isoprenaline and papaverine might inhibit the oxytocin-induced contractions of the isolated rat uterus by accumulation of cyclic AMP.

The inhibitory response of the isolated rat uterus to Aspaminol was greatly potentiated by aminophylline, while imidazole did not decrease the response to Aspaminol. Further, Aspaminol had little influence on phosphodiesterase activity. Therefore, this potentiation by aminophylline cannot be explained on the basis of aceumulation of the intracellular cyclic AMP. The potentiation of the action of Aspaminol by aminophylline may result from its effect on the cell membrane. In view of these results, it can be concluded that the noncompetitive antioxytocin action of Aspaminol is not concerned with the amount of intracellular cyclic AMP increased by inhibiting phosphodiesterase. Takagi, Takayanagi and Fujie (9) and also Takagi et al. (10) divided "papaverine-like" antispasmodics into two groups according to their mechanisms of action; strong basic substances or most synthetic antispasmodics such as Aspaminol bclong to the first group and weak bases such as papaverine and neutral substances as isoamylesters belong to the second. The present results support the theory that there are two different mechanisms for the so-called papaverine-like antispasmodics.

The inhibitory response of the taenia to Aspaminol was little influenced by caffeine in contrast to the results obtained with the rat uterus. This difference could be due to species and organ differences.

\section{REFERENCES}

1) Robison, G.A., Butcher, R.W. and Sutherland, E.W.: Ann. Rev. Biochem. 39, 149 (1968)

2) Triner, L., Vullilioz, Y., Schwartz, I. and Nahas, G.G.: Biochem. biophys. Res. Commum. 40, 64 (1970)

3) Pö̈h, G. A.Nd Klkoveit, W.R.: Life Sci. 10, 133 (1971)

4) Takayanagi, I., Uchida, M., Inatomi, N., Tomiyama, A. and Takagi, K.: Japan. J. Pharmacol. 22, 869 (1972) 
5) Inatomi, N., Takayanagi, I., Uchida, M. and Takagi, K.: Eur. J. Pharmacol. (in press)

6) Andersson, R.: Linköping Lniversity Medical Dissertation, Linköping, Sweden (1972)

7) Polacek, I., Bolan, J. and Daniel, E.E.: Can. J. Physiol. Pharmacol. 49, 999 (1971)

8) Marshall, J.M. and Kroegner, E.A.: Phil. Trans. R. Soc. Lond, 265, 135 (1973)

9) Takagi, K., Takayanagi, I. and Fujie, K.: Chem. Pharm. Bull. 6, 716 (1958)

10) Takagi, K., Ishida, Y., Moriroki, H. ANd Hara, K.: Yalugahu Zasshi 81, 1708 (1961) (in . Japanese)

11) Van Rossum, J.M.: Archs int. Pharmacodyn. Thír. 143, 299 (1963)

12) Takayanigi, J.: Pharmacometrics 2, 131 (1969)

13) Pö́r, G.: Arch. Pharmak, exp. Path. 268, 272 (1971)

14) Krishna, G., Weiss, B. ANd Brodic, B.B.: J. Pharmacol. exp. Ther. 163, 379 (1968)

15) Lineweaver, H. and Burk, D.: J. Amer. Chem. Soc. 56, 658 (1934)

16) Dixon, M.: Biochem. J. 55, 170 (1953)

17) Mitznegf, P., Heim, F. and Mliythalir, B.: Life Sci. 9, 121 (1970)

18) Mutzntgi, P., Hachi, B. and Hem, F.: life Sci. 9, 975 (1970)

19) Takagi, K., Takayavagi, I. ANd Tsuchida, Y.: Japan. J. Pharmacol. 22, 403 (1972) 